\title{
Combining Bias-correction on Regional Climate Simulations and ENSO Signal for Water Management: Case Study for Tampa Bay, Florida, U.S.
}

\author{
Syewoon Hwang ${ }^{1,2 *}$ and Jose Hernandez ${ }^{3}$ \\ ${ }^{1}$ Department of Agricultural and Biological engineering, University of Florida, Gainesville, Florida \\ ${ }^{2}$ Water institute, University of Florida, Gainesville, Florida \\ ${ }^{3}$ Bureau of Ocean Energy Management, New Orleans, Louisiana \\ (Received June 1, 2012; Revised October 5, 2012; Accepted October 15, 2012)
}

\section{ENSO 패턴에 대한 MM5 강수 모의 결과의 유역단위 성능 평가: 플로리다 템파 지역을 중심으로}

\author{
황세운 ${ }^{1,2 *} \cdot$ 호세 헤르난데즈 ${ }^{3}$ \\ 1플로리다 대학교, 농공학과, 플로리다 대학교, 수자원 연구소, \\ 3루이지애나 해양에너지 관리국 \\ (2012년 6월 1일 접수; 2012년 10월 5일 수정; 2012년 10월 15일 수락)
}

\begin{abstract}
As demand of water resources and attentions to changes in climate (e.g., due to ENSO) increase, long/ short term prediction of precipitation is getting necessary in water planning. This research evaluated the ability of MM5 to predict precipitation in the Tampa Bay region over 23 year period from 1986 to 2008. Additionally MM5 results were statistically bias-corrected using observation data at 33 stations over the study area using CDF-mapping approach and evaluated comparing to raw results for each ENSO phase (i.e., EI Niño and La Niña). The bias-corrected model results accurately reproduced the monthly mean point precipitation values. Areal average daily/monthly precipitation predictions estimated using block-kriging algorithm showed fairly high accuracy with mean error of daily precipitation, $0.8 \mathrm{~mm}$ and mean error of monthly precipitation, $7.1 \mathrm{~mm}$. The results evaluated according to ENSO phase showed that the accuracy in model output varies with the seasons and ENSO phases. Reasons for low predictions skills and alternatives for simulation improvement are discussed. A comprehensive evaluation including sensitivity to physics schemes, boundary conditions reanalysis products and updating land use maps is suggested to enhance model performance. We believe that the outcome of this research guides to a better implementation of regional climate modeling tools in water management at regional/seasonal scale.
\end{abstract}

Key words: MM5, Precipitation simulations, Statistically bias-corrected, Block-kriging, ENSO, Tampa Bay

\section{INTRODUCTION}

Many applications of climate modeling methodolo- gies in forecasting crop yields over the Southeastern United States (SEUS, which include the state of Florida) have been reported in the last decades (e.g. Hansen 
et al. 1998, Alexandrov and Hoogenboom, 2001) after a better understanding of El Niño/La Niña Southern Oscillation (ENSO) variability and its impact at global and regional scales on precipitation were exposed by Ropelewesky and Halpert (1986), Handler (1990), and Leung et al. (1999). Since those early studies, researchers have used observational or simulated data germane to ENSO into crop models (Shin et al., 2006, Olatinwo et al., 2010) and insurance analytical tools to predict yields and evaluate risk of planting agricultural commodities (Cabrera et al., 2006, Liu et al., 2008). Worldwide, similar agro-meteorological approaches (Zhang et al., 2008, Deng et al., 2010) have started and continued in development; however many of these studies rely on statistical or dynamical downscaling which provides a fundamental role in developing forecasting methodologies for regional crop and food production (Cocke et al., 2007).

Precipitation is a key factor in rain-fed agricultural production at SEUS, and the quality of its prediction is important for diverse socio-economic sectors, health food security, and ecosystem services including water management and tourism (Scmidt et al., 2001, Meinke et al., 2005). Even with the modern observational resources (meteorological station networks, satellite and diverse remote sensing information) and modeling advances (with improved quality and higher time and spatial resolution, and data assimilation techniques), it is still a challenge to accurately predict frequency and amount of precipitation.

Deficiencies at global scale in representing the range of amplitude and frequencies of ENSO (Lin, 2007) and tropical processes like the Inter-tropical Convergence Zone (ITCZ) (Liu et al., 2012), are evident in state-of the-art general circulation models (GCMs), and thus such model outputs should be used cautiously. These two recent studies confirm that tropical warm and cold ocean surface temperatures in modern GCMs cause unrealistic thermodynamic gradients, atmospheric circulations and precipitation patterns. Exploring such deficiencies helps climate scientists to understand the interactive dynamic of earth system components and to improve their representation in coupled global models which are limited to resolve smaller scale terrestrial processes. For this reason, much attention has been recently taken to improve downscaling techniques for regional applications. Important advances have been reported in the physically-based regional climate models (RCMs), a technique referred to as 'dynamical downscaling' (Murphy, 1999; Schmidli et al., 2006). While recent studies have been demonstrated that dynamical downscaling shows good skills in reproducing regional scale climate variability and extremes (Pal et al., 2004; Frei et al., 2006), it also has been noted that applications of RCMs typically requires to correct systematic biases of the results (particularly for precipitation) for further application (Hwang et al., 2011; Wood et al., 2004; Fowler et al., 2007).

Hwang et al. (2011) recently set up the Pennsylvania State University (PSU)-National Center for Atmospheric Research (NCAR) Fifth-Generation Mesoscale Model (MM5; Grell et al., 1994) for the Tampa Bay region and its ability to reproduce observed spatiotemporal variability in precipitation had been evaluated. Their research demonstrated that raw MM5 results were positively biased and statistical bias-correction method significantly improved the precipitation predictions in spatiotemporal aspects. They concluded that the bias-corrected results represent realistic precipitation patterns at daily and seasonal time scale so that the results could be useful for long-term water resource planning. Previous research on the assessment of RCMs including MM5 (e.g., Colle et al., 1999) have primarily focused on climatologic impacts by examining how the model simulates atmospheric phenomena or by focusing on comparing only point predictions of climatic data to available observations. However predicting precipitation volumes over watershed areas can also be important for water resource planning and management applications, particularly those that used lumped hydrologic models.

This study examines model results from Hwang et al. (2011) in aspects of ENSO signal representation. The point-based precipitation predictions were spatially averaged using block-kriging technique and evaluated comparing to the observed average precipitation for classified ENSO year over the target area. The goal of this paper is to quantitatively evaluate the ability of MM5 to reproduce ENSO signal of precipitation from reanalysis data over the Tampa Bay region.

\section{TARGET AREA AND DATA}

\subsection{Target area}

Tampa Bay is the largest estuary in Florida and extends about $50 \mathrm{~km}$ inland from the Gulf of Mexico. The openwater section is made up by four segments. Of these, Hillsborough Bay, the smallest of these segments, 


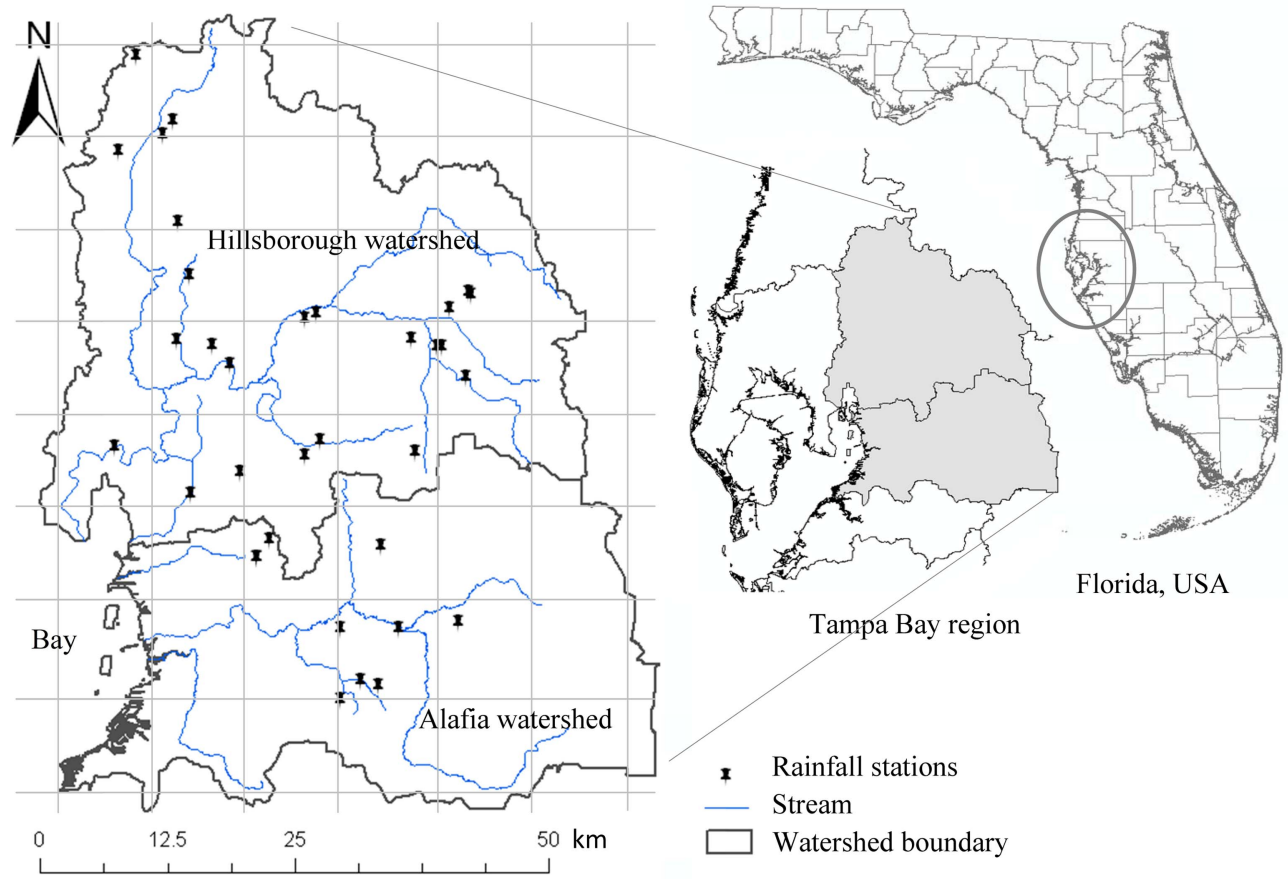

Fig. 1. Map of target area and rainfall stations used for bias-correction. The grids on the watershed map represent how the MM5 $9 \mathrm{~km} \times 9 \mathrm{~km}$ grid configuration covers the target area.

receives fresh water from Hillsborough and Alafia rivers that cover a large portion of the highly populated metropolitan area of Tampa. In the Tampa Bay region, a diverse regional water supply system that includes surface water and groundwater treatment plants, regional well fields, and a seawater desalination have been operated by Tampa Bay Water (TBW). Because this area is dominantly rainfall-driven system, an accurate forecast of climate forcing and change of climate variability have been important issues in time-scale varying water planning. Particularly, the Hillsborough $\left(1850 \mathrm{~km}^{2}\right)$ and Alafia $\left(1380 \mathrm{~km}^{2}\right.$ ) watersheds (which cover most area in Tampa Bay) play an important role to manage the water system for reliable resources. This study evaluated the bias-corrected MM5 results over the Hillsborough and Alafia watersheds mapped in Fig. 1.

\subsection{Precipitation data}

Raw MM5 precipitation predictions are bias-corrected using the point observations to remove systematic errors in MM5 outputs. Daily precipitation point data were collected from 33 observational stations maintained by several agencies (Tampa Bay Water, National
Oceanic and Atmospheric Administration (NOAA), Southwest Florida Water Management District (SWFWMD), and United States Geological Survey (USGS)). The locations and managing agencies for the stations are listed in Table 1 and the station network of precipitation data was represented in Fig. 1. The period of record varies to the stations from less than 10 years (e.g., BUD stations) to more than 100 years (Plant City and St. Leo station) as depicted in Fig. 2. The historical data period may influence the bias-correction skill because it is a primary requirement to develop reliable distribution function for bias-correction.

\subsection{MM5 modeling results}

Hwang et al. (2011) ran MM5 model from 1986 to 2008 using the well-known National Centers for Environmental Prediction and the National Center for Atmospheric Research (NCEP/NCAR) global reanalysis data (Kalnay et al., 1996) as initial and boundary condition. The MM5 was used to downscale reanalysis precipitation data in two nested domains at $27 \times 27 \mathrm{Km}^{2}$ and $9 \times 9 \mathrm{Km}^{2}$ covering the southeastern United States and Florida respectively. The 23 years simulation was 
Table 1. Precipitation data used to evaluate and bias-correct MM5 predictions

\begin{tabular}{|c|c|c|c|c|}
\hline \multicolumn{2}{|r|}{ Station identification } & \multirow[b]{2}{*}{ Owner } & \multicolumn{2}{|c|}{ Coordinate } \\
\hline ID & Name & & Lat. & Lon. \\
\hline 1 & BUD-05 & $\mathrm{TBW}^{1}$ & 27.942 & 82.273 \\
\hline 2 & BUD-JMOORE_RG & TBW & 27.926 & 82.286 \\
\hline 3 & CBR-BIG FISH RAIN & TBW & 28.371 & 82.407 \\
\hline 4 & CNR-CM-2 RAIN & TBW & 28.160 & 82.071 \\
\hline 5 & CNR-CM-6 RAIN & TBW & 28.114 & 82.100 \\
\hline 6 & CNR-T1 RAIN & TBW & 28.120 & 82.131 \\
\hline 7 & CNR-T2 RAIN & TBW & 28.086 & 82.077 \\
\hline 8 & CNR--T3 RAIN & TBW & 28.148 & 82.093 \\
\hline 9 & CNR-T-4 RAIN & TBW & 28.113 & 82.106 \\
\hline 10 & CNR-T-5 RAIN & TBW & 28.162 & 82.074 \\
\hline 11 & CYB-CY-7 RAIN & TBW & 28.176 & 82.354 \\
\hline 12 & CYB-TOT RAIN & TBW & 28.224 & 82.365 \\
\hline 13 & CYC-C-3 RAIN & TBW & 28.301 & 82.380 \\
\hline 14 & CYC-N.GATE RAIN & TBW & 28.314 & 82.371 \\
\hline 15 & CYC-PLANT RAIN & TBW & 28.286 & 82.425 \\
\hline 16 & Hills River St Pk & SWFWMD $^{2}$ & 28.143 & 82.227 \\
\hline 17 & MB RN USGS & $\mathrm{USGS}^{3}$ & 28.097 & 82.313 \\
\hline 18 & MBR 3C RAIN & TBW & 28.114 & 82.331 \\
\hline 19 & MBR-BOOSTER & TBW & 28.119 & 82.367 \\
\hline 20 & NEB-DAYS INN RAIN & TBW & 28.002 & 82.303 \\
\hline 21 & NEB-TAMPA 22 RAIN & TBW & 28.030 & 82.223 \\
\hline 22 & Plant City Rainfall & $\begin{array}{l}\text { NOAA/ } \\
\text { SWFWMD }\end{array}$ & 28.020 & 82.127 \\
\hline 23 & Rainfall at Tampa Dam & USGS & 28.024 & 82.428 \\
\hline 24 & RES-P-S-50 & TBW & 27.800 & 82.202 \\
\hline 25 & RES-P-S-71 RAIN & TBW & 27.817 & 82.182 \\
\hline 26 & RES-P-S-78 RAIN & TBW & 27.813 & 82.164 \\
\hline 27 & Ruskin NWS & $\mathrm{NOAA}^{4}$ & 27.700 & 82.400 \\
\hline 28 & SCHM-2 RAIN & TBW & 27.937 & 82.162 \\
\hline 29 & SCH-SC-1 & TBW & 27.863 & 82.202 \\
\hline 30 & SCH-SC-17 RAIN & TBW & 27.869 & 82.084 \\
\hline 31 & SCH-SC-4 RAIN & TBW & 27.863 & 82.144 \\
\hline 32 & St Leo Rainfall & SWFWMD & 28.336 & 82.260 \\
\hline 33 & TBC-STRUCTURE-162 & TBW & 27.982 & 82.352 \\
\hline
\end{tabular}

1: TBW: Tampa Bay Water

2: SWFWMD: SouthWest Florida Water Management District

3: USGS: U.S. Geological Survey

4: NOAA: National Oceanic and Atmospheric Administration

performed in monthly sections. Such a sectional simulation in regional climate modeling would lead spin-up problem in precipitation as implemented by Laprise (2008) and Lee and Berbery (2012). For this reason 1.5 days of each month was not considered in evaluating model performance though we reasonably assume the spin up period could be neglected with a minimum

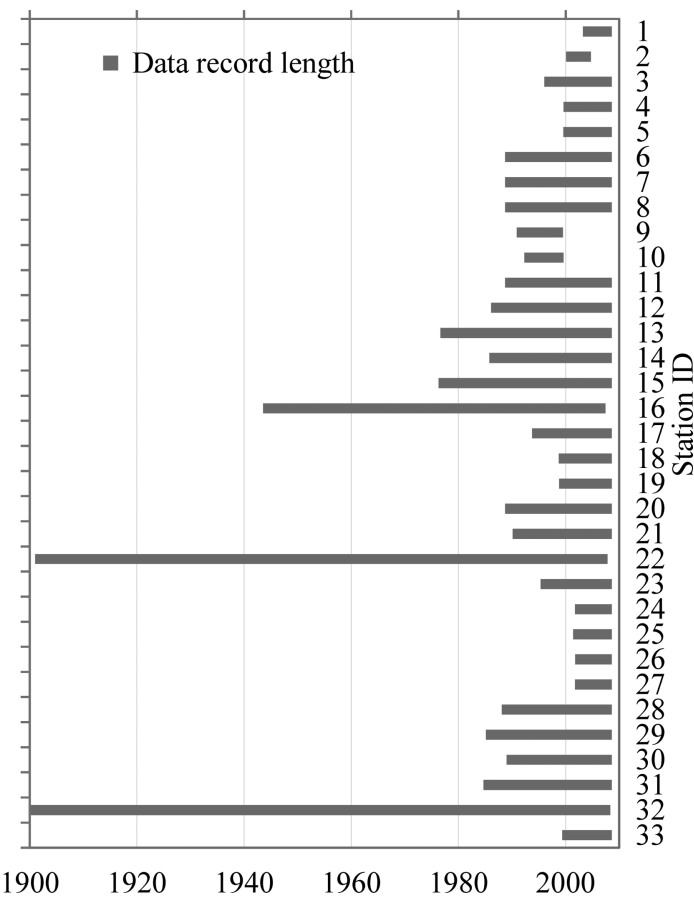

Fig. 2. The period of available data record for 33 stations.

impact in the model evaluation. The Grell scheme (Grell et al., 1994), a simple approach for clouds formation taking updraft and downdraft at the bottom at top of mixed layer atmospheric circulation, was implemented in the experiments. We set the planetary boundary layer (PBL) parameterization of medium-range forecast scheme (Hong and Pan, 1996), where nonlocal diffusion and precipitation physics are considered in predicting PBL development. The NCAR community climate model (CCM2) radiation scheme (Kiehl et al., 1996) evaluates the multispectral reflectivity and transmissivity in homogeneous atmospheric layers to compute upward and downward radiative fluxes. We selected the five layer soil model (Dudhia, 1996) which calculates temperature tendencies by taking the residual of the surface energy budget (including sensible, latent and radiative heat fluxes) and keeping the substrate at a constant temperature. Finally the 25-category U.S. Geological Survey (USGS) land use dataset with 1-km horizontal spacing were used. The geographical domains and preliminary results of MM5 bias-correction were evaluated by Hwang et al. (2011) in terms of reproducing spatiotemporal variability of daily precipitation at point scale. As described above, this study estimates the spatially averaged precipitation predictions over the 
target area and evaluates these results in aspects of ENSO representation.

\section{METHODOLOGY}

\subsection{Statistical bias-correction}

This study used a cumulative distribution function (CDF) mapping approach (Panofsky and Brier, 1968) to bias-correct the MM5 $9 \times 9 \mathrm{~km}^{2}$ predictions. This method was originally developed for removing the biases in GCM results at monthly time scale by Wood et al. $(2002,2004)$. The correction process could improve the climate predictions in reproducing mean climatology and spatiotemporal distribution of climate variable (Hwang et al., 2011). It should be, however noted that applying the CDF mapping bias-correction method at specific temporal scale (e.g., daily) is limited in reproducing temporal variability at other scale such as monthly or inter-annual variability as demonstrated by Haerter et al. (2011) and Hwang et al. (2012).

In this study, bias-correction was conducted for each month on daily basis. The predicted CDFs over the study period for the nearest grid to each station were compared to the observed CDFs of the corresponding station. Each predicted precipitation value is then corrected to the value that corresponds to the same probability of exceedance from the observed CDFs. The detailed procedure and an experiment for CDF mapping bias-correction have been well described by Hwang et al. (2011).

In the case of using observations which have been applied for hydrologic modeling (generally, irregularly distributed point observations), the bias-corrected results are considered as the estimations at the observed locations so that the corrected results could be directly used as hydrologic model input because those results have the statistical properties (daily mean and variance) of observation and the spatial resolution is identical to observation distribution. On the other hand, use of observations at other location or different spatial resolution from the hydrological model configuration, may have need of further process to estimate data at right locations where climate input data of hydrologic model are required.

\subsection{Block-kriging}

To produce arealy integrated bias-corrected daily and monthly rainfall total estimates, bias-corrected daily point precipitation predictions were block-kriged using an ordinary kriging algorithm over the Alafia and Hillsborough Watersheds. Subsequently daily block-kriged values were summed for each month to produce monthly totals. Cross-validation of the arealy integrated field was conducted by comparing the block-kriged estimate from predicted values to the block-kriged value from the observed data. The average variogram between a particular observation (or prediction) at location $u_{\alpha}$ and the precipitation at all of the points within area $\mathrm{A}$, $\bar{\gamma}\left(u_{\alpha}, A\right)$ required for the block-kriging algorithm was calculated using the following equation (Goovaerts, 1997),

$$
\bar{\chi}\left(u_{\alpha}, A\right)=\frac{1}{N} \sum_{i=1}^{N} \chi\left(u_{\alpha}, u_{i}\right)=\frac{1}{N} \sum_{i=1}^{N} \chi\left(u_{\alpha}, u_{\alpha}+h_{i}\right)
$$

where $h_{i}$ is the distance between $u_{\alpha}$ and $u_{i}, \chi\left(u_{\alpha}, u_{\alpha}+h_{i}\right)$ is the variogram between points $u_{\alpha}$ and $u_{\alpha}+h_{i}$, and $N$

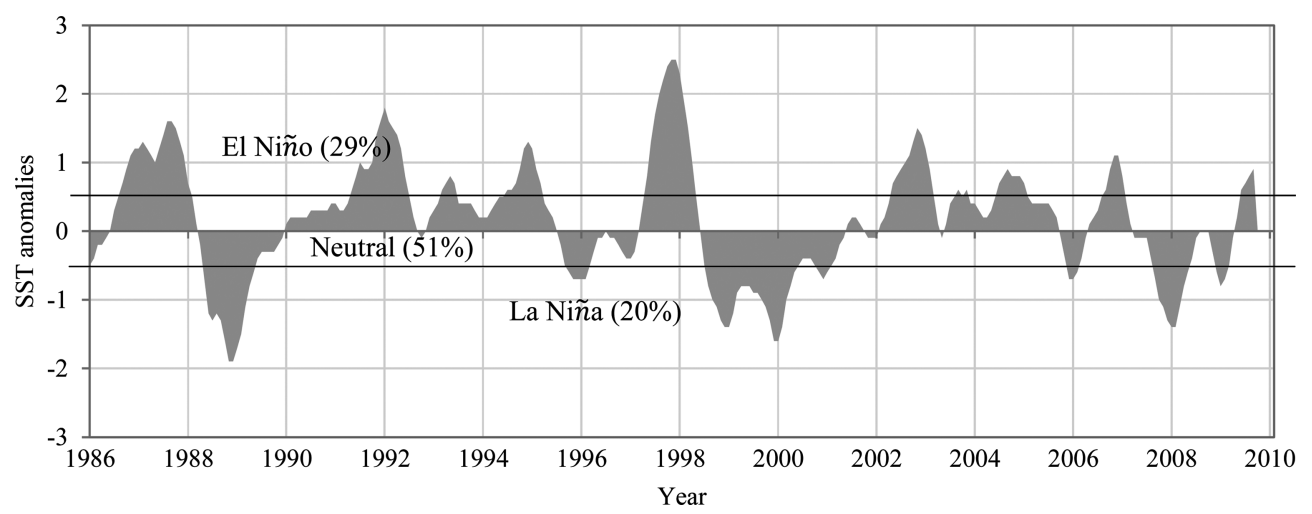

Fig. 3. Time series plots of the Oceanic Niño 3.4 SST indices (ONI) based on base period climatology from 1971 to 2000 . The thresholds of $\pm 0.5^{\circ} \mathrm{C}$ are represented as solid lines to indicate ENSO events. Percentages of period for each ENSO phase are presented on the figure. Units for temperature are ${ }^{\circ} \mathrm{C}$. 
is the number of points $u_{i}=u_{\alpha}+h_{i}$ discretizing the area, A.

The experimental variogram $2 \varkappa(h)$ for the observed and simulated precipitation data was calculated using the following formula (Goovaerts, 1997).

$$
2 \gamma(h)=\frac{1}{N(h)} \sum_{\alpha=1}^{N(h)}\left[z\left(u_{\alpha}\right)-z\left(u_{\alpha}+h\right)\right]^{2}
$$

where $N(d)$ denotes the number of pairs of observations separated by vector $h$, and $z\left(u_{\alpha}\right)$ is the spatial observation field (i.e. observed or simulated precipitation) at location $u_{\alpha}$.

For calculations, we developed algorithm codes using the language of technical computing, MATLAB (version R2010b).

\subsection{ENSO phase classification}

The model performance was evaluated for each ENSO phase (i.e., El Niño, Neutral, and La Niña), separately to investigate the ability of MM5 to reproduce ENSO trends in rainfall. Each phase was defined using the Oceanic Niño index (ONI) from the NOAA climate prediction center (http://www.cpc.ncep.noaa.gov). The ONI is the three month running mean of sea surface temperature (SST) anomalies in the Niño 3.4 region $\left(5^{\circ} \mathrm{N}-5^{\circ} \mathrm{S}, 120^{\circ}-170^{\circ} \mathrm{W}\right)$ from the Extended Reconstruction SST v3b dataset (Smith et al., 2008), based on the 1971-2000 base period. Cold (La Niña) and warm (El Niño) episodes are defined by the threshold of $\pm 0.5^{\circ} \mathrm{C}$ as shown in Fig. 3. The analysis of errors for each classified ENSO phase was conducted for both the bias-corrected monthly predictions and the arealy integrated predictions.

\section{RESULTS AND DISCUSSION}

Bias-corrected MM5 predictions and area averaged predictions over two watersheds were quantitatively evaluated using the observations available over the target area. The accuracy of the precipitation estimates at daily or monthly time scale was quantified using the mean error (ME) and root mean square error (RMSE). In addition, the actual kriging error was normalized by the predicted kriging standard deviation to evaluate the performance of kriging algorithm; mean error of approximately zero, and a root mean square error of approximately one indicate the proper performance of kriging estimator.

Daily and monthly precipitation totals predicted by
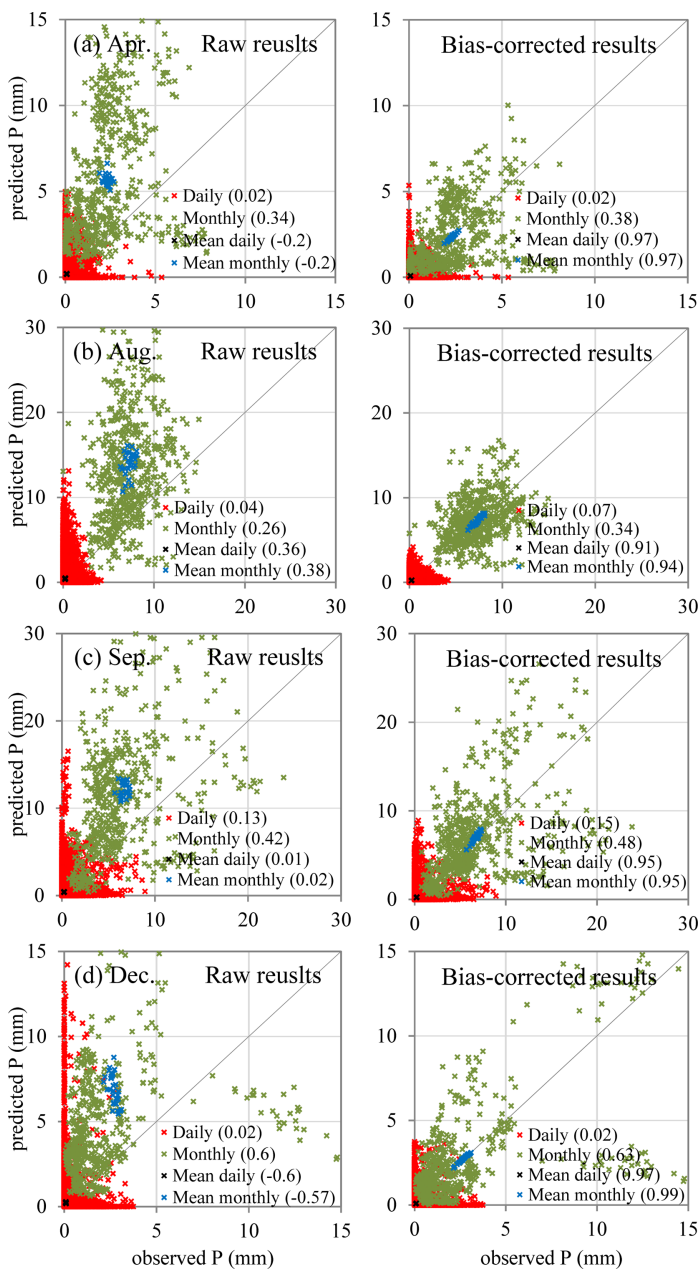

Fig. 4. Comparisons of daily (red points) and monthly (green points) raw model predictions (first column) and bias-corrected results (second column) vs. observations for (a) Apr., (b) Aug., (c) Sep., and (d) Dec. Red and brown points compare the individual daily and monthly observed versus simulated precipitation values for each station over the 23 year period, respectively. Black and blue points compare the observed versus simulated daily and monthly average precipitation for each station over the 23 year, respectively. Correlation coefficients are also presented on each panel.

the MM5 model at the $9 \mathrm{~km}$ grid spacing were evaluated at the 33 rain gage locations in the Tampa Bay region for the 23 year period from 1986 to 2008. MM5 performance was assessed by cross-validating predicted daily and monthly point and total watershed precipitation in each month. Fig. 4 compares raw and biascorrected daily/monthly simulation results to the obser- 
Table 2. Error statistics (ME, RMSE) of monthly total precipitation by ENSO phase (El Niño, Neutral, and La Niña). Statistics are calculated for bias-corrected predictions over all 33 stations. Bold values indicate the largest RMSE

\begin{tabular}{|c|c|c|c|c|c|c|c|c|}
\hline & \multicolumn{8}{|c|}{ Bias-corrected monthly errors (units: mm) } \\
\hline & \multicolumn{2}{|c|}{ Overall } & \multicolumn{2}{|c|}{ El Niño } & \multicolumn{2}{|c|}{ Neutral } & \multicolumn{2}{|c|}{ La Niña } \\
\hline & ME & RMSE & ME & RMSE & $\mathrm{ME}$ & RMSE & ME & RMSE \\
\hline Jan. & -5.00 & 44.15 & 0.94 & 33.53 & -11.36 & 53.46 & -6.50 & 38.48 \\
\hline Feb. & -5.63 & 52.80 & -24.01 & 55.54 & 2.99 & 50.44 & -7.85 & 47.87 \\
\hline Mar. & -3.21 & 43.85 & -23.40 & 48.65 & 0.44 & 39.04 & 11.13 & 34.74 \\
\hline Apr. & 2.23 & 62.65 & 18.72 & 37.58 & -3.79 & 64.08 & 10.10 & 55.19 \\
\hline May. & 1.93 & 78.61 & 7.64 & 96.69 & 0.06 & 70.44 & 1.94 & 32.50 \\
\hline Jun. & -1.81 & 117.77 & 2.26 & 80.94 & -1.51 & 126.06 & -25.10 & 75.67 \\
\hline Jul. & 2.62 & 116.53 & 48.51 & 139.94 & -18.82 & 100.98 & 30.18 & 92.31 \\
\hline Aug. & 6.94 & 116.23 & 50.74 & 150.81 & -1.77 & 98.35 & -22.34 & 71.78 \\
\hline Sep. & 4.97 & 126.46 & -29.01 & 105.65 & -0.29 & 93.51 & 107.76 & 192.72 \\
\hline Oct. & 6.26 & 65.32 & -2.48 & 47.99 & 12.83 & 61.49 & 3.42 & 77.16 \\
\hline Nov. & 1.93 & 61.41 & -6.31 & 38.02 & -8.22 & 32.01 & 24.90 & 95.27 \\
\hline Dec. & 0.77 & 113.59 & -25.87 & 174.18 & 18.06 & 42.43 & 19.56 & 46.64 \\
\hline Average & 1.00 & 83.28 & 1.48 & 84.13 & -0.95 & 69.36 & 12.27 & 71.69 \\
\hline
\end{tabular}

Table 3. Kriging error and normalized kriging error statistics (ME, RMSE) of daily and monthly total block-kriged precipitation distributions. Statistics are calculated over the 23 year period for block-kriging predictions

\begin{tabular}{lcccccccc}
\hline \hline & \multicolumn{2}{c}{ Daily $(\mathrm{mm})$} & \multicolumn{2}{c}{ Monthly $(\mathrm{mm})$} & \multicolumn{2}{c}{ Normalized daily $(-)$} & \multicolumn{2}{c}{ Normalized monthly $(-)$} \\
\cline { 2 - 9 } & ME & RMSE & ME & RMSE & ME & RMSE & ME & RMSE \\
\hline Jan. & -0.38 & 8.56 & -9.90 & 21.91 & -0.03 & 0.63 & -0.14 & 0.46 \\
Feb. & -0.20 & 7.88 & -6.19 & 35.04 & -0.01 & 0.58 & -0.08 & 0.50 \\
Mar. & -0.17 & 9.38 & -5.40 & 43.15 & -0.01 & 0.69 & -0.07 & 0.58 \\
Apr. & 0.17 & 8.88 & 3.99 & 43.93 & 0.02 & 1.21 & 0.11 & 1.15 \\
May. & 0.51 & 8.47 & 12.83 & 79.71 & 0.04 & 0.62 & 0.19 & 1.11 \\
Jun. & 0.72 & 13.76 & 21.68 & 101.10 & 0.05 & 1.01 & 0.29 & 1.39 \\
Jul. & 0.72 & 12.31 & 21.50 & 93.30 & 0.05 & 0.90 & 0.29 & 1.30 \\
Aug. & 6.99 & 12.77 & 27.09 & 86.52 & 0.45 & 0.83 & 0.38 & 1.23 \\
Sep. & 0.19 & 15.07 & 6.74 & 114.92 & 0.35 & 1.10 & 0.08 & 1.58 \\
Oct. & 0.05 & 9.00 & 1.74 & 54.71 & 0.00 & 0.66 & 0.02 & 0.76 \\
Nov. & -0.01 & 8.16 & -0.66 & 62.31 & 0.00 & 0.60 & -0.01 & 0.84 \\
Dec. & 0.37 & 12.63 & 12.30 & 78.16 & 0.03 & 0.91 & 0.17 & 1.11 \\
Average & 0.75 & 10.57 & 7.14 & 68.73 & 0.08 & 0.81 & 0.10 & 0.99 \\
\hline
\end{tabular}

vations. The raw MM5 results were found to be positively biased, in general overestimating precipitation especially for the dry season throughout the target area. The bias-correction approach described above removed these biases and significantly improved the model error ( $>0.9$ of correlation coefficients over the stations). Additionally, the MM5 predictions somewhat reproduce spatial structure of monthly precipitation for the wet season (i.e., Jun., Jul., Aug., and Sep.) but not for dry season, and it was significantly improved by biascorrection for both seasons as shown in Fig. 4. Hwang et al. (2011) derived similar results for Tampa Bay region using more point observations and presented that the raw model predictions overestimate number of wet days with low rainfall. They also found that the bias-correction procedure made the predictions reproduce the observed temporal mean and variance but fail to improve correlation between predictions and observations.

Table 2 summarizes the ME and RMSE for the biascorrected monthly total precipitation predictions estimated for each classified ENSO phase, separately. 
These results indicated that bias-corrected MM5 prediction better reproduced the observed monthly precipitation amount and pattern during neutral period. Additionally the month to month mean error (bias) and RMSE were more highly variable for El Niño and La Niña years. Predictions deteriorate in February, March, May, July, August and December during El Niño years, and for September, October, and November during La Niña years.

Table 3 includes the ME and the RMSE for the daily and monthly block-kriging and normalized block-kriging estimates. These error statistics show how blockkriging the bias-corrected daily precipitation fields over the watersheds reproduced the observed block-kriged
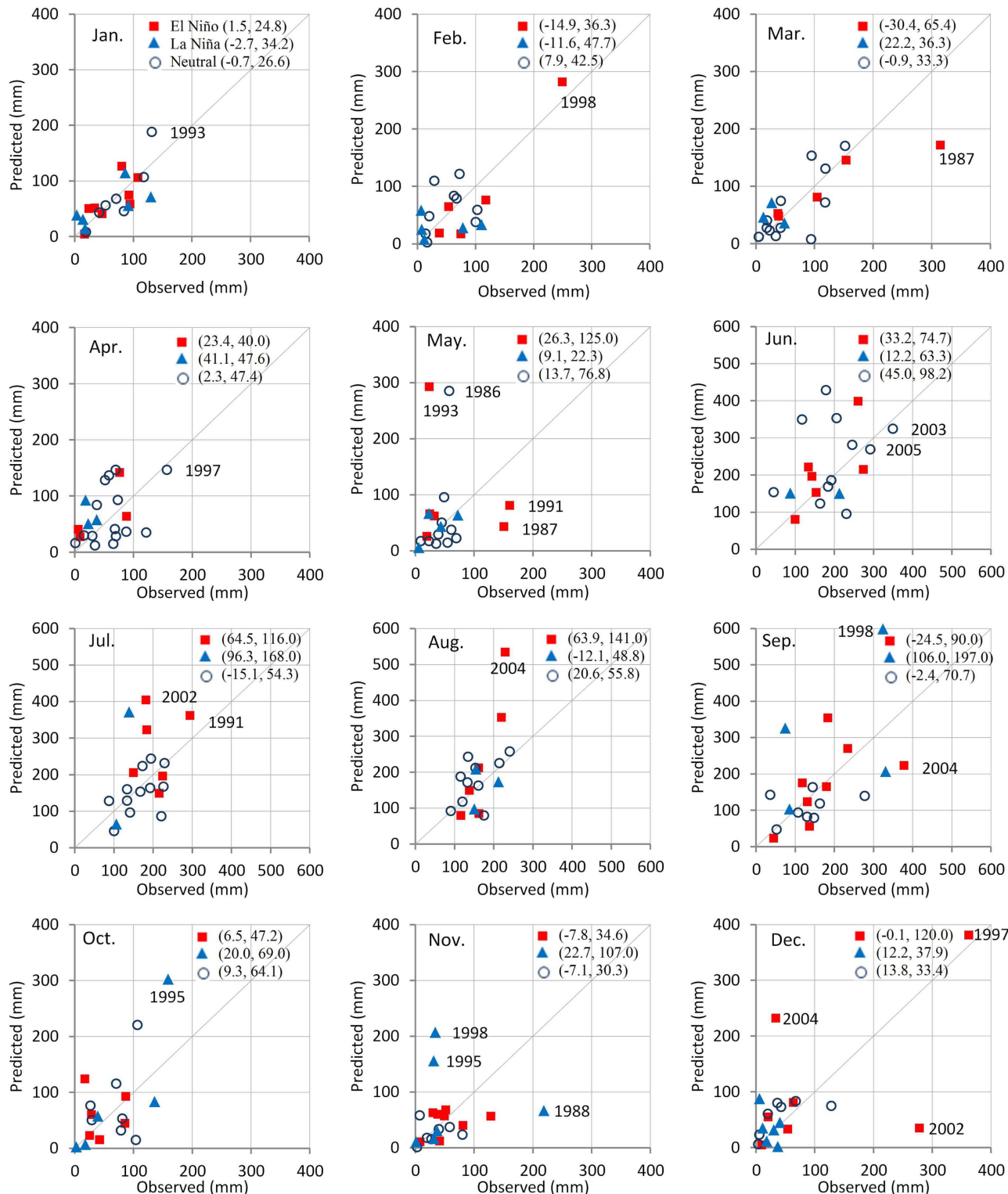

Fig. 5. Scatter plots of MM5 vs. observed precipitation for each month. Each point represents the block-kriged monthly rainfall for each year. The squared, triangular, and circled dots indicate the comparisons for El Niño, Neutral, and La Niña period, respectively. Mean error and root mean square error for each ENSO phase are also presented on each figure. The years with several significantly overestimated or underestimated predictions, and the case with largest precipitation for each month are indicated on the graphs. 
rainfall. The ME of daily predictions ranges from -0.38 $\mathrm{mm}$ in January to $6.99 \mathrm{~mm}$ in August and an average RMSE ranging from $7.88 \mathrm{~mm}$ in February to 15.07 $\mathrm{mm}$ in September over the 23 years. The ME and RMSE for the arealy integrated monthly total precipitation ranged from $-9.90 \mathrm{~mm}$ in January to $27.09 \mathrm{~mm}$ in August and from $31.91 \mathrm{~mm}$ in January to 114.92 $\mathrm{mm}$ in September, respectively. The average normalized block-kriging ME and RMSE are 0.08 and 0.81 for daily prediction and 0.10 and 0.99 for monthly, respectively indicating that the kriging algorithm produced unbiased results and estimated its prediction errors accurately.

The RMSE of the block-kriged predictions for the dry season (October to May) ranged from $21.91 \mathrm{~mm}$ to $78.71 \mathrm{~mm}$, and are smaller than observed standard deviations which range from $56.96 \mathrm{~mm}$ to $108.07 \mathrm{~mm}$ (not presented in the paper). This indicates that using the block-kriged model results should be better to predict areal precipitation than using the mean rainfall from long term climatology data for the dry season. On the other hand, for the wet season (May to September) the RMSE of block-kriged predictions are larger than observed standard deviation, indicating using blockkriged MM5 predictions in the wet season could result in larger errors than using the long-term wet season mean. This finding indicates that dynamically downscaled reanalysis data shows different skills for the wet and dry seasons in reproducing daily and monthly areal precipitation amounts even after bias-correction. We have to remind that the bias-correction was performed independently for each calendar month on daily basis and it is plausible to expect a consistent positive or negative bias in this analysis.

Fig. 5 shows scatter plots of observed versus biascorrected simulated arealy averaged monthly precipitation totals. The monthly precipitation totals were plotted for each ENSO phase separately, and the years with significantly overestimated or underestimated predictions are indicated on the graphs. The areal averaged predictions errors for the wet season (June to September) were comparatively high as also shown in Table 3 . Prediction errors for the dry season (October to April) were lower than the wet season with mean errors less than $10 \mathrm{~mm}$ and RMSE generally less than $60 \mathrm{~mm}$, except for December. The average error of the predictions for December was large because the model underestimated the high December 2002 monthly precipitation volume $(298.13 \mathrm{~mm})$, and overestimated the low 2004 precipitation $(33.53 \mathrm{~mm})$. These two years were categorized as El Niño and it indicates that the error over all simulation period were attenuated by averaging the under/overestimated biases varying to ENSO phase.

The implications of the results from this study would give some lessons to consider when predicting precipitation using combined reanalysis data and RCMs techniques. Among the factors which can influence the quality of precipitation predictability in such approaches is the physical configuration implemented originally in the reanalysis modeling system and later in setting the regional climate model. For instance, when comparing observed precipitation with that from widely used reanalysis products, including NCEP-NCAR, Bosilovich et al. (2008) found varied weakness and strengths depending on the region in a global study. They reported a positive bias for the dry and wet season of $0.62 \mathrm{~mm} \mathrm{day}^{-1}$ and $0.85 \mathrm{~mm}$ day $^{-1}$, respectively in the Equator $-30^{\circ} \mathrm{N}$ region.

Additionally using one physics configuration for the long-term simulation analyzed in this work likely impact the seasonal variation of the MM5 model performance. El Niño and La Niña periods could extent over several seasons, and thus the dominance among synoptic (interaction between cold and warm fronts) and sub-regional processes (e.g. sea breeze, lake breeze) can make a significant difference in precipitation prediction if the model is not configured with the appropriate physics for a particular period of the year. The analysis presented in this study only considers one physics configuration, and this may become an important source of error in rainfall predictions. A sensitivity analysis to physics schemes to evaluate the model skills to describe ocean-land-atmosphere interactions, cloud formation, microphysics and atmospheric radiative processes is advised to improve simulations results. On the other hand, using different reanalysis data (boundary conditions) could drive to different outputs. Particularly in Florida, the ocean-land temperature gradient is a key factor in the formation of convergence fronts in summer that can influence the patterns of precipitations. Reanalysis products do not necessarily present similar land and sea surface temperatures consequently resulting in distinct thermodynamic circulations. Another possible factor that can influence the quality of predictions is the land use change (Lee and Berbery, 2012; Hernandez et al., 2012). Florida has undergone significant landscape transformation during the last decades as confirmed by the Florida Division of Forestry (2005). 
Specifically, urbanization has been competing with agriculture and the changes in land surface parameters influence humidity over developed areas altering precipitation. An in-depth exploration of these factors would be advisable in analyzing the simulation results.

\section{CONCLUSIONS}

This study presents a quantitative evaluation of dynamically downscaled precipitation predictions using mesoscale model (MM5) for the Tampa Bay region over the 23 years period from 1986 to 2008 . For model validation and bias-correction, data from 33 rainfall stations distributed over the target area were used. The raw and bias-corrected MM5 precipitation predictions were evaluated with respect to the variability of temporal ENSO phase signal.

Statistical bias-correction was conducted using a CDF mapping. The significant reduction of predicted errors was achieved by bias-correction. The results indicate that the bias-corrected MM5 can reproduce historical mean precipitation, but that it still provides timing errors at daily and monthly precipitation occurrence. In previous study, it has been shown that biascorrection only improved the results to reproduce the observed temporal mean and variance for each station and the spatial correlation over the area and correlation between prediction and observation has no significant improvement even after bias-correction.

Block-kriged daily and monthly precipitation totals were found to reproduce areal averages block-kriged from observed data especially for the dry season. Larger errors occurred in wet season when convective storms dominate, with reasonable agreement in the dry season. Comparison of the areal averaged monthly predictions to observations for the 23 year study period showed that the model somewhat accurately reproduces the temporal pattern of monthly precipitation and that the areal averaged bias-corrected block-kriged results would be useful for generating the rainfall inputs needed to run lumped hydrologic models.

Errors for the bias-corrected monthly total precipitation point predictions were estimated for each ENSO phase, and these results showed that the predictions tend to deteriorate for El Niño and La Niña years compared to neutral years. Block-kriged monthly predictions for two watersheds also showed comparatively large errors for several El Niño and La Niña years. After exposing possible cause of errors, we conclude that the MM5 precipitation prediction under the current configuration do not accurately reproduce the ENSO phase climatology for the Tampa Bay region. To improve ENSO phase specific prediction accuracy for historical simulations, ENSO phase specific bias-correction and alternative initial/boundary conditions (other than NCEP/NCAR reanalysis) or model physics configuration for each season should be considered.

\section{적 요}

수자원의 수요 증가와 ENSO (El Niño/La Niña Southern Oscillation) 등의 기후변화 현상으로 인한 수자원 공급의 불안정 요소가 제기됨에 따라, 수자원 관리 계획 수립 시 장/단기강우 모의의 중요성이 강조 되고 있다. 본 연구에서는 미국 플로리다 템파 지역의 두 개 유역을 대상으로 1986년부터 2008년까지의 MM5 지역기후모델을 이용한 강우모의 결과를 시험지 역의 33개 관측자료와 CDF-mapping 기법을 이용하여 통계적으로 보정하였으며 그 결과를 바탕으로 $\mathrm{ENSO}$ 패턴에 따른 모델의 성능을 평가하였다. 보정된 MM5 일 강우 모의결과는 대체적으로 각 관측소의 월 평균 강우량 (ME: $1.0 \mathrm{~mm}$ )을 잘 모의하는 것으로 나타닜다. 블락-크리깅 기법을 이용하여 추정된 유역 평균 일/월 강우량 또한 관측치를 잘 재현하였다(일 강우 $\mathrm{ME}$ : $0.8 \mathrm{~mm}$, 월 강우 $\mathrm{ME}: 7.1 \mathrm{~mm}$ ). 한편, ONI (Oceanic Niño index)를 이용하여 구분한 ENSO 패턴에 따른 강우 모의치를 분석한 결과, 월별 엘리뇨/라니냐 해에 대한 유역 단위의 강우량 모의 성능이 상이한 것으로 나타났다. 이 원인으로 한정된 모수화 적용 및 모델 경계자료 오차 등을 제시하고 이에 대한 보정 방법 개선 등의 추가 연구의 필요성을 지적하였다. 본 연구 는 $\mathrm{ENSO}$ 패턴을 고려한 월별 기후모델 결과를 활용 함에 있어 유의점을 제시하였기에, 우기와 건기에 대한 수자원 관리를 위한 적용 등에 유용하게 활용될 것으 로 기대된다.

\section{REFERENCES}

Alexandrov, V. A., and G. Hoogenboom, 2001: Climate variation and crop production in Georgia, USA, during the twentieth century. Climate Research 17, 33-43.

Bosilovich, M. G., J. Chen, F. R. Robertson, and R. F. Adler, 2008: Evaluation of global precipitation in reanalyses. Journal of Applied Meteorology and Climatology 47, 
2279-2299. doi: 10.1175/2008JAMC1921.1

Cabrera, V. E., C. W. Fraisse, D. Letson, G. Podestá, and J. Novak, 2006: Impact of climate information on reducing farm risk by optizing crop insurance strategy. Transactions of the ASABE 49(4), 1223-1233.

Cocke, S., T. E. LaRow, and D. W. Shin, 2007: Seasonal rainfall predictions over the southeast United States using the Florida State University nested regional spectral model. Journal of Geophysical Research 112, D04106. doi:10.1029/2006JD007535.

Colle, B. A., K. Westrick, and C. F. Mass, 1999: Evaluation of MM5 and Eta-10 precipitation forecasts over the Pacific Northwest during the cool season. Weather Forecasting 14, 137-154.

Deng, X., J. Huang, F. Qiao, R. L. Naylor, W. P. Falcon, M. Burke, S. Rozelle and D. Battisti, 2010: Impacts of El NinoSouthern Oscillation events on China's rice production. Journal of Geographical Sciences 20(1), 3-16. DOI:10.1007/ s11442-010-0003-6.

Dudhia, J., 1996. A multi-layer soil temperature model for MM5. Preprints, the 6th PSU/NCAR Mesoscale Model Users Workshop, Boulder CO, July, National Center for Atmospheric Research, 49-50.

Florida Division of Forestry, 2005: Florida's Forest Resources Plan Setting the Course for 2030: 1. Present Condition of Florida's Forest Resources, retrieved: January 10, 2010, from: http://www.fl-dof.com/plans_support/ps_pdfs/ FlForestResourcesActionPlan12_2005.pdf

Fowler, H. J., S. Blenkinsop, C. Tebaldi, 2007: Linking climate change modeling to impacts studies: recent advances in downscaling techniques for hydrological modeling. International Journal of Climatology 27, 1547-1578.

Frei, C., R. Schll, S. Fukutome, J. Schmidli, and P. L. Vidale, 2006: Future change of precipitation extremes in Europe: An intercomparison of scenarios from regional climate models. Journal of Geophysical Research 111, D06105. doi:10.1029/2005JD005965.

Grell, G. A., J. Dudhia, and D. R. Stauffer, 1994: A description of the fifth-generation Penn State/NCAR Mesoscale Model (MM5). NCAR Tech. Note NCAR/TN-398+STR, 117 and 122.

Haerter, J. O., S.Hagemann, C. Moseley, C. Piani, 2011: Climate model bias correction and the role of timescales. Hydrology and Earth System Sciences 15, 1065-1079. DOI: 10.5194/hess-15-1065-2011.

Handler, P., 1990: USA corn yields, the El Niño and agricultural drought: 1867-1988. International Journal of Climatology 10, 819-828.

Hansen, J. W., A. W. Hodges, and J. W. Jones, 1998: ENSO influences on agriculture in the southeastern United States. Journal of Climate 11, 404-411.

Hernández, J. L., S. Hwang, F. Escobedo, A. H. Davis, and J. W. Jones, 2012: Land use change in central Florida and sensitivity analysis based on agriculture to Urban Extreme conversion. Weather, Climate, and Society 4(3), 200-211.

Hong, S. Y., and H. L. Pan, 1996: Non-local boundary layer vertical diffusion in a medium-range forecast model. Monthly Weather Review 124, 2322-2339.

Hwang, S., W. Graham, J. S. Geurink, and A. Adams, 2012: Hydrologic implications of errors in dynamically downscaled and bias-corrected climate model predictions. Journal of Hydrology, under review.

Hwang, S., W. Graham, J. L. Hernández, C. Martinez, J. W. Jones, and A. Adams, 2011: Quantitative Spatiotemporal Evaluation of Dynamically Downscaled MM5 Precipitation Predictions over the Tampa Bay Region, Florida. Journal of Hydrometeorology 12, 1447-1464. doi:10.1175/ 2011JHM1309.1

Kalnay, E., M. Kanamitsu, R. Kistler, W. Collins, D. Deaven, L. Gandin, M. Iredell, S. Saha, G. White, J. Woollen, Y. Zhu, M. Chelliah, W. Ebisuzaki, W. Higgins, J. Janowiak, K. C. Mo, C. Ropelewski, J. Wang, A. Leetmaa, R. Reynolds, R. Jenne, D. Joseph, 1996: The NCEP/NCAR 40-year reanalysis project. Bulletin of the American Meteorological Society 77(3), 437-470.

Kiehl, J. T., J. J. Hack, G. B. Bonan, B. A. Boville, B. P. Briegleb, D. L. Williamson, and P. J. Rasch, 1996: Description of the NCAR Community Climate Model (CCM3), NCAR/TN-420 STR, NCAR Technical Note.

Laprise, R., 2008: Regional climate modeling. Journal of Computational Physics 227, 3641-3666.

Lee, S. J., and E. H. Berbery, 2012: Land cover change effects on the climate of the La Plata basin. Journal of Hydrometeorology 13, 84-102.

Leung, L. R., A. H. Hamlet, D. P. Lettenmaier, and A. Kumar, 1999: Simulation of the ENSO hydroloclimate signals in the Pacific Northwest Columbia River basin. Bulletin of the American Meteorological Society 80, 2313-2329.

Lin, J. L., 2007: Interdecadal variability of ENSO in 21 IPCC AR4 coupled GCMs. Geophysical Research Letters 34, L12702, doi:10.1029/2006GL028937.

Liu, J., C. Men, V. E. Cabrera, S. Uryasev, and C. W. Fraisse, 2008: Optimizing Crop Insurance under Climate Variability. Journal of Applied Meteorology and Climatology 47, 2572-2580.

Liu, H., M. Zhang, and W. Lin, 2012: An Investigation of the Initial Development of the Double-ITCZ Warm SST Biases in the CCSM. Journal of Climate 25, 140-155.

Meinke, H., P. Devoil, G. L. Hammer, S. Power, R. Allan, R. C. Stone, C. Folland, and A. Potgieter, 2005: Rainfall Variability at Decadal and Longer Time Scales: Signal or Noise? Journal of Climate 18, 89-96.

Murphy, J., 1999: An evaluation of statistical and dynamical techniques for downscaling local climate. Journal of Climate 12, 2256-2284.

Olatinwo, R. O., J. O. Paz, R. C. Kemerait Jr, A. K. Culbreath, and G. Hoogenboom, 2010: El Niño-Southern Oscillation (ENSO): Impact on tomato spotted wilt inten- 
sity in peanut and the implication on yield. Crop Protection 29(5), 448-453.

Pal, J. S., F. Giorgi, and X. Bi, 2004: Consistency of recent European summer precipitation trends and extremes with future regional climate projections. Geophysical Research Letter 31, L13202, doi:10.1029/2004GL019836.

Panofsky, H. A., and G. W. Brier, 1968: Some applications of statistics to meteorology. Pennsylvania State University, University park, PA, USA, 224 pp.

Ropelewski, C. F., and M. S. Halpert, 1986: North American precipitation and temperature patterns associated with the El Niño-Southern Oscillation (ENSO). Monthly Weather Review 114, 2352-2362.

Schmidli, J., C. Frei, and P. L. Vidale, 2006: Downscaling from GCM precipitation: a benchmark for dynamical and statistical downscaling methods. International Journal of Climatology 26, 679-689.

Schmidt, N., E. K. Lipp, J. B. Rose, and M. E. Luther, 2001: ENSO Influences on Seasonal Rainfall and River
Discharge in Florida. Journal of Climate 14, 615-628.

Shin, D. W., J. G. Below, T. E. LaRow, S. Cocke, and J. J. O'Brien, 2006: The Role of an Advanced Land Model in Seasonal Dynamical Downscaling for Crop Model Application. Journal of Applied Meteorology and Climatology 45, 686-701.

Wood, A.W., L. R. Leung, V. Sridhar, and D. P. Lettenmaier, 2004: Hydrologic implications of dynamical and statistical approaches to downscaling climate model outputs. Climatic Change 62, 189-216.

Wood, A. W., E. P. Maurer, A. Kumar, and D. P. Letternmaier, 2002: Long-range experimental hydrologic forecasting for the eastern United States. Journal of Geophysical Research 107, 4429. doi:10.1029/2001JD000659.

Zhang, T., J. Zhu, X. Yang, and X. Zhang, 2008: Correlation changes between rice yields in North and Northwest China and ENSO from 1960 to 2004. Agricultural and Forest Meteorology 148(6-7), 1021-1033. 